\title{
DRAWING LESSONS FROM THE BOOM OF TEMPORARY JOBS IN SPAIN*
}

\author{
Juan J. Dolado, Carlos García Serrano and Juan F. Jimeno
}

\begin{abstract}
We review some lessons from the Spanish experience of using temporary employment contracts for regular jobs since 1984. The focus is on the role of fixed-term contracts with low severance pay, which have substituted for reform of employment protection legislation for permanent contracts. We consider the main findings about this reform on the Spanish labour market in the light of the main theoretical implications derived from models dealing with dual labour markets, and address why the incidence of temporary work has remained highly persistent, around $33 \%$ of salaried employment, in the 1990 s, despite several reforms aimed at reducing it.
\end{abstract}

If one looks for a country to test for the different effects of temporary work contracts on the labour market, Spain provides a fascinating case study. Up to the early 1980s, permanent work contracts open ended contracts subject to man datory severance payments represented more than $90 \%$ of all contracts, with the remaining temporary contracts being mainly of seasonal nature which employers could only use to hire workers performing non regular productive activities, for example, in agriculture or in the tourist industry. In 1984, with the unemploy ment rate at $20.1 \%$, the Spanish government tried to implement a significant change in Employment Protection Legislation (EPL) by liberalising temporary contracts in two main respects: first, their use was extended to hire employees performing regular activities; and, second, they entailed much lower dismissal costs than the regular permanent contracts. As a result, the proportion of tem porary employees in total (salaried) employment surged in the second half of the 1980s, staying above 30\% since 1990 (Fig. 1). A clear sign that employers took full advantage of the newly available flexibility device is that a large fraction of tem porary workers have been hired under fixed term contracts while other types of temporary contracts (probationary, seasonal, etc.), which are more representative in other European labour markets, have remained relatively unimportant (Fig. 2).

During the 1990s, despite a series of countervailing labour market reforms in 1994, 1997 and, more recently, in 2001, which provided a less stringent EPL for permanent contracts and considerable restrictions for the use of fixed term contracts, the share of temporary employees has only marginally declined from $35.4 \%$ in 1995 to $32.0 \%$ in 2001 . Over this period, more than $90 \%$ of new hires have been signed under temporary contracts, and the duration of employment spells has very much decreased. Thus, in just a decade, a fairly regulated labour

\footnotetext{
* We are grateful to Alison Booth, Ignacio Conde, Jeff Frank, Miguel A. Malo, Barbara Petrongolo, Donald Storrie, Luis Toharia, participants in seminars at Amsterdam, Bocconi, Essex, Montreal and Southampton universities, three anonymous referees and an editor, for very helpful comments and suggestions. Special thanks to Virginia Hernánz and Mario Izquierdo for their research assistance, and to Luis Sauto for providing us with the data about regional funds for employment policies. The usual caveat applies.
} 


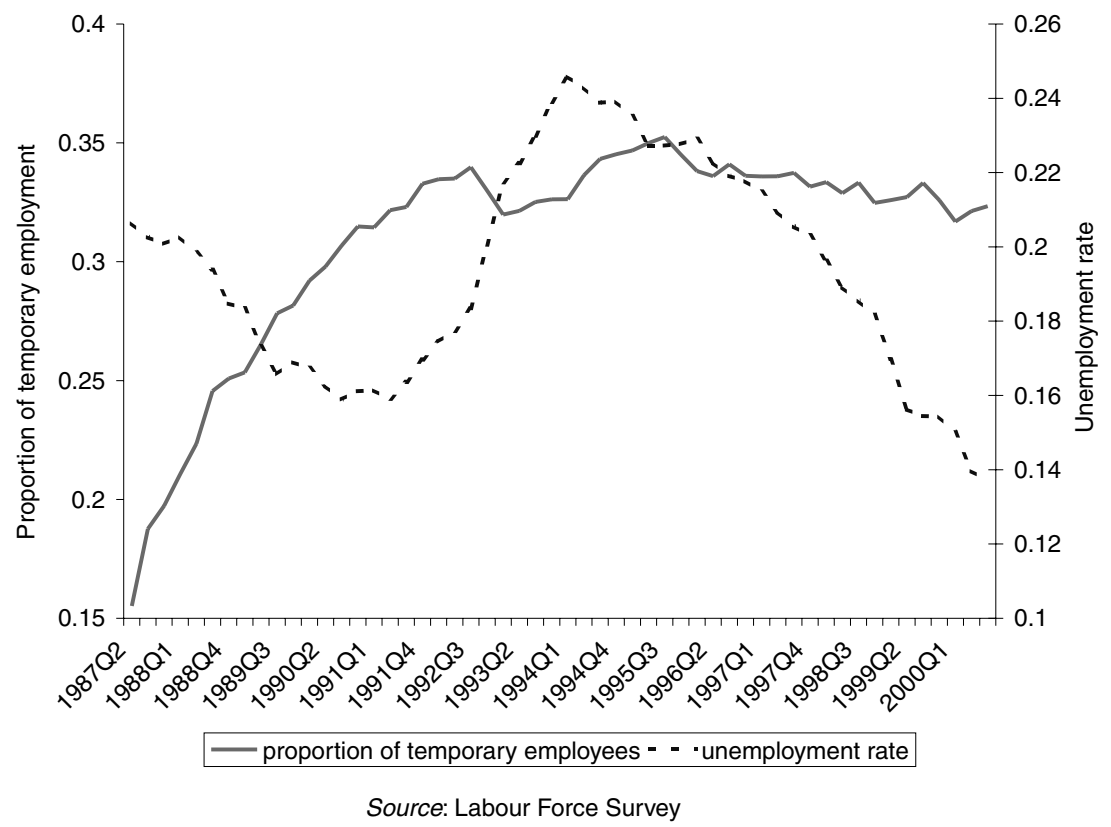

Fig. 1. Temporary Employment (as proportion of employees) and Unemployment Rate. Spain, 19872000

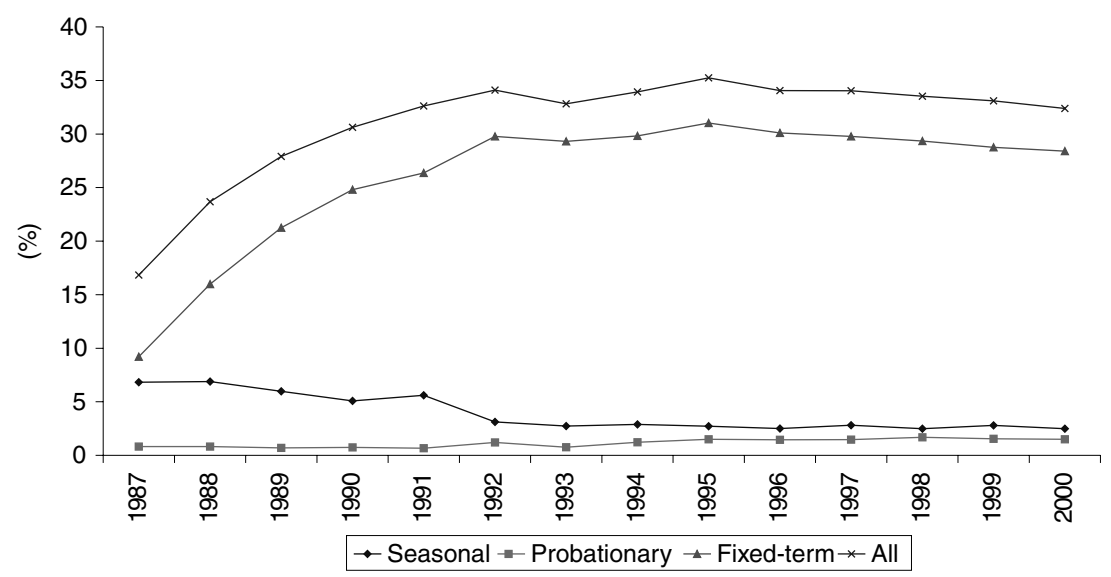

Fig. 2. Temporary Employment Contracts by Type (as proportion of employees). Spain, 19872000 
market with high dismissal costs and strong unions' bargaining power at wage determination turned into a very divisive labour market, where around two thirds of the employees enjoyed permanent contracts subject to a strict EPL, and kept the high bargaining power of the past, while the remaining one third are workers under fixed term contracts entailing much less favourable employment condi tions.

The implications of fixed term contracts for the various dimensions of the la bour market (eg labour turnover, unemployment, wage determination and pro ductivity growth), have been extensively analysed in a large number of theoretical and empirical contributions which rely heavily on the Spanish experience. A gen eral conclusion is that the most natural way to interpret the rapid upsurge of temporary work in Spain from the mid 1980s to the early 1990s is as a quick transition process towards a steady state composition of employment in which the equilibrium ratio of temporary to permanent employees would be determined, among other parameters, by:

(i) the elasticity of substitution between both types of workers

(ii) the relative wage of workers under each of those contracts

(iii) the gap in firing costs between both contracts (taking into account the decisions by labour courts about unfair dismissals)

(iv) the difference in hiring costs, including the explicit subsidies to the conversion of temporary contracts into permanent ones

(v) the volatility of labour demand along the business cycle, and

(vi) the average growth rate.

As will be discussed all of those factors have contributed in different ways to explain the dramatic growth of the incidence of temporary jobs in Spain until the early 1990s, where the steady state seems to have been reached. Later, however, despite exhibiting a small reduction (shown in Fig. 1), the persistent evolution of that share is less well understood given the above mentioned sequence of coun tervailing reforms implemented during the 1990s.

The goal of this paper is twofold. First, we compare the main theoretical pre dictions obtained in the literature with the available empirical evidence regarding the consequences of a very segmented labour market, like the one in Spain. Our aim is to draw useful lessons for other countries, if they were to follow the same kind of policies, and for the future of the Spanish labour market, if the current state of affairs were to remain unchanged. Second, we address the puzzle of why the share of temporary employment remains so high to date, despite the policy reversals aimed at its reduction.

As highlighted in the Introduction to this Symposium, under the general heading of temporary contracts, there are different types of contracts and even different regulations of the same contracts across countries. Hence, Section 1 is devoted to describing the institutional peculiarities regarding the use of tem porary contracts in Spain. In particular, we review in detail all the legal changes in the regulations that have taken place since 1984; we also offer a political economy interpretation of why those reforms were implemented. In Section 2, we 
review the main theoretical predictions about the effects of dual employment contracts on the functioning of the labour market that have been derived in the literature. Following those predictions, Section 3 takes stock of the main empir ical evidence drawn from the Spanish experience. For that, we focus on the effects of the outburst in the share of temporary employment during the 1980s, and its subsequent persistence over the $1990 \mathrm{~s}$, on a wide variety of labour market dimensions, including employment volatility, the provision of training, the evo lution of labour productivity and the wage distribution. Next, in Section 4, we try to answer the important question of why the share of temporary employment has remained so high after the flexibility enhancing reforms of permanent contracts vis à vis fixed term contracts in the 1990s and 2001. We show that the puzzle can be explained in terms of the different patterns followed by the private and the public sectors in their hiring procedures after the 1997 reform. Finally, Section 5 concludes.

\section{The Institutional Background}

The first democratic governments in Spain after 1978 found it hard to dismantle the system of industrial relations under General Franco's dictatorship, which was based on rigid labour laws and the ban of trade unions in exchange for almost lifetime job stability. The legalisation of trade unions and the restoration of a proper collective bargaining system between employers and workers in the late 1970s gave rise to a strong increase in the bargaining power of the latter at wage setting. Yet, those changes were not accompanied by a parallel significant reduc tion in EPL since it was feared that such a reform could endanger the smooth political transition to democracy. Thus, after the approval of the so called Workers' Statute (Ley del Estatuto de los Trabajadores) in 1980, the two main institutional features which have characterised the Spanish labour market over the last two decades can be summarised as follows: ${ }^{1}$

(i) a high degree of employment protection both against dismissals and functional and geographical mobility.

Under permanent contracts, firing costs depend on a worker's seniority and on the reasons for dismissals, which may be due to:

(a) 'objective' causes (worker's incompetence, lack of adaptation to the job post, absenteeism)

(b) economic, technological, organisational or productive causes, and

(c) 'disciplinary' causes.

Dismissed workers under permanent contracts can appeal to a labour court, and severance payments depend on the judge's decision. Collective dismissals (roughly those affecting more than $10 \%$ of the firm's labour force over a period

\footnotetext{
${ }^{1}$ See Jimeno and Toharia (1994) for further details on the institutional characteristics of the Spanish labour market.
} 
of 90 days) can be justified only on reason b), and require administrative approval. $^{2}$

(ii) The predominance of collective bargaining at the provincial/industry level as the means for setting wages, working hours and other employment conditions, complemented by negotiations at other levels of bargaining (national, firm level), where wages paid to workers under fixed term contracts ought to be the same as wages paid to workers under permanent contracts in the same occupational category and doing a similar job

Nonetheless, as is discussed in Section 4, there is evidence of wage gaps against temporary workers. ${ }^{3}$

Reforms of the labour legislation introduced in 1980 started as early as 1984 . The first reform encouraged the use of fixed term contracts for regular activities and, in contrast with permanent contracts, entailed much lower severance pay ments and their termination could not be appealed to labour courts. In the 1990 s, by contrast, reforms were aimed at undoing the liberalisation of 1984 and reducing the incidence of temporary employment. In 1994, the conditions for 'fair' dismissals of workers under permanent contracts were relaxed, while con ditions for the use of fixed term contracts were restricted. In 1997, the employers' confederation (CEOE) and the two major unions (UGT and CC.OO) reached an agreement to reform the system of work contracts and the structure of collective bargaining. The agreement called for the creation of a new permanent contract with lower firing costs in case of 'unfair' dismissals, entailing a mandatory redundancy pay of 33 days' wages per year of seniority with a maximum of 24 months of wages (instead of 45 and 42, respectively, under the regular permanent contracts). This new contract could be used for most new hires, with the ex ception of workers aged 3044 years with unemployment spells below one year. Moreover, the government introduced significant rebates of social security con tributions for workers under the new permanent contracts. In principle, the 1997 reform envisaged the new contract to be in effect for a period of four years. In 2001, however, when the new permanent contracts were supposed to expire, fearing that their elimination would exert a negative effect on job creation, the government allowed them to remain in effect and extended their use to hire

\footnotetext{
${ }^{2}$ Judges may declare dismissals 'fair', 'unfair' or 'null'. If a dismissal is justified by either 'objective' or economic, technological, organisational or productive reasons and it is declared 'fair' then the worker receives a severance payment of 20 days' wages per year of seniority with a maximum of 12 months' wages. If the dismissal is declared 'unfair', the employer can choose between the worker's reinstatement and a higher severance payment of 45 days' wages per year of seniority with a maximum of 42 month's wages (33 days' wages per year of seniority with a maximum of 24 month's wages under the new permanent contract introduced in 1997) together with the wages corresponding to the period between the date of the dismissal and the date of the court's decision. If the dismissal is declared 'null', then the worker must be reinstated and the wages corresponding to the period between the date of the dismissal and the date of the court's decision must be paid. Collective dismissals entailed severance payments of 20 days' wages per year of seniority with a maximum of 12 months' wages, although, in practice, to achieve workers' agreement, which eases the administrative approval, severance payments are much higher.

${ }^{3}$ Workers under fixed-term contracts receive wages $10 \%$ lower than those received by similar workers under permanent contracts (that is, after controlling for observable characteristics). Something similar happens in other countries; on France, see Blanchard and Landier (2002).
} 
other groups of workers. ${ }^{4}$ Furthermore, in a explicit move to reduce the share of temporary contracts, the government also introduced a severance payment of 8 days' wages per year of seniority for workers whose fixed term contracts are not renewed. 5

Summing up, the Spanish EPL being one the most rigid EPL in Europe was first relaxed in 1984 by easing the use of fixed term contracts for non seasonal productive activities while keeping intact the EPL of permanent contracts. As the proportion of temporary jobs surged, the recent reforms of the 1990s and 2001 have aimed at achieving a more 'balanced' situation between both types of con tracts both by restricting the use of fixed term contracts and by reducing manda tory firing costs under new permanent contracts.

The understanding of the political determinants of labour market reforms has recently become one of the key topics of the research on European unemployment (Saint Paul, 1996, 2000b). In the specific case of the Spanish EPL reforms, a simple indicator of the 'political support' for those reforms is the ratio between the number of workers under regular permanent contracts entailing ' 45 days' of redundancy pay and the sum of total employees (permanent and temporary) and the unemployed. ${ }^{6}$ A value of this ratio above 0.5 means that workers under regular permanent contracts would be the 'insiders' and that unions would consequently try to protect their interests. Conversely, a ratio below 0.5 signifies that the rest of the workers (the sum of temporary workers plus the ones under the new permanent contracts) and the unemployed will be those dictating the unions' goal. Fig. 3 depicts such a ratio since 1987 (the first year for which data on temporary em ployment are available). Since it is most likely that the indicator was well above 0.5 in 1984, the introduction of fixed term contracts for regular activities can be rationalised as the only way forward which was politically feasible at a time when unemployment was very high and increasing, employment creation was very low and, hence, there were very few job alternatives for displaced workers. Eventually, with the widespread use of fixed term contracts and a further increase in unem ployment, the indicator decreased to the extent that it was clearly below 0.5 by 1993 . That suggests the opening of a 'window of opportunity' for the reforms that later took place in 1994, 1997 and 2001, helping to explain why the prevailing interests of

\footnotetext{
${ }^{4}$ Before March 2001, the eligible groups were young workers aged 18-29, long-term unemployed registered at the public employment office for at least twelve months, unemployed aged 45 or more, disabled people and workers whose contracts are transformed from temporary into permanent. After March 2001, the eligible groups are young people aged 16-30, long-term unemployed registered at the public employment office for at least six months, unemployed aged 45 or more, disabled people, and unemployed women in sectors where they are under-represented.

${ }^{5}$ Severance payments for dismissals of workers under fixed-term contracts before the termination of the contract have been similar to those applying to permanent contracts since 1984 . However, given that most fixed-term contracts have very short duration, these firing costs do not seem relevant.

${ }^{6}$ The use of this indicator is justified under the following assumptions regarding the objectives and the constituency of the unions:

(a) that their only goal is to maximise the expected wage (i.e. the wage times the probability of employment)

(b) that they protect the interest of the median worker, and

(c) that their potential constituency is formed by all salaried workers (both permanent and temporary) and the unemployed.
} 


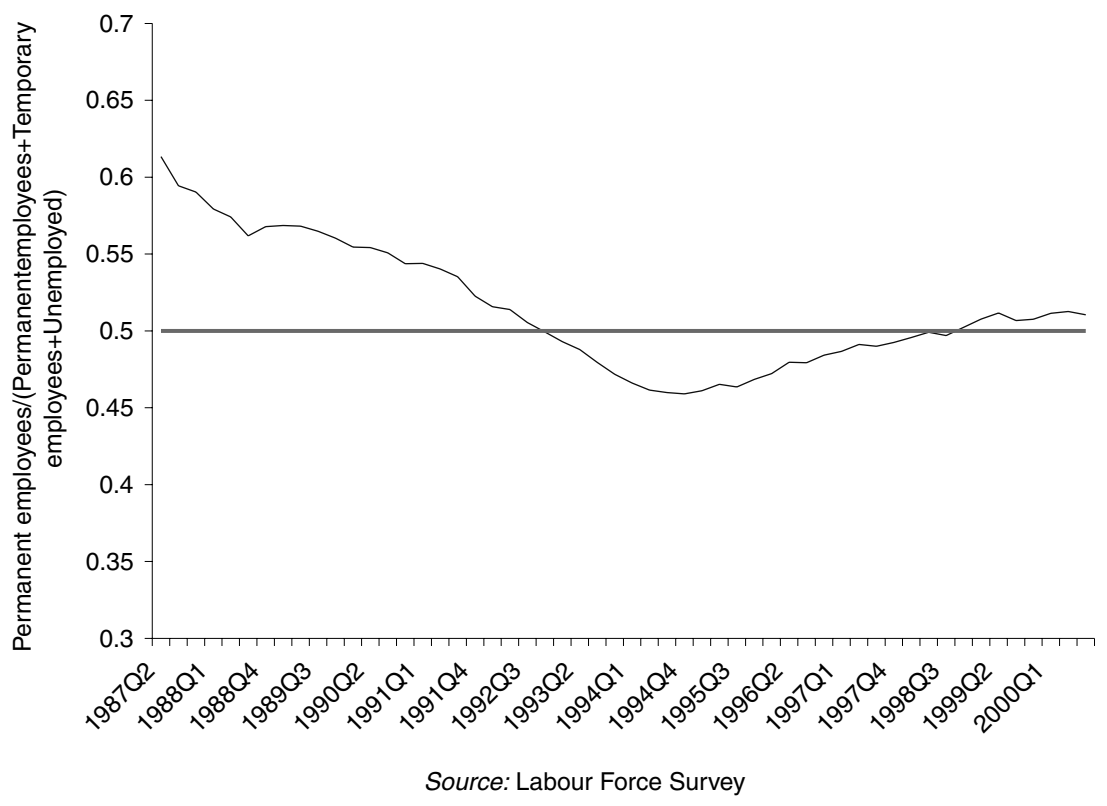

Fig. 3. An Indicator for 'Political Support' for EPL Reforms

the workers under fixed term contracts, new permanent contracts and the unem ployed in favour of higher labour market flexibility, led to a less stringent EPL.

\section{A Look at the Theory}

There are many theoretical approaches to analyse the effects of fixed term contracts on the labour market. Each of them isolates several mechanisms through which the specific characteristics of those contracts (determined dur ation, lower dismissal costs, possibility of renewal etc.) affect the working of the labour market. Here, we will summarise the main features of four of those ap proaches. First, there are dynamic models of labour demand with adjustment costs that provide the basic tools to analyse the determinants of the share of fixed term contracts in dual labour markets where contracts with and without firing costs coexist. Second, there are matching and search models which provide extensions of the equilibrium unemployment theory to the case where there are two kinds of jobs and firms face the trade off of paying firing costs and having stable workers, or avoiding them and having workers heavily engaged in the search process. Third, there are efficiency wage models focusing on the effects of high turnover on productivity and wages. Finally, there are wage bargaining models that stress how different turnover costs alter workers' relative bargaining power in the distribu tion of the generated surplus. However, since, to the best of our knowledge, an integrated framework embedding all these different mechanisms is not yet 
available, we briefly discuss each of them in turn, highlighting some relevant implications drawn from one or two representative contributions in each of the approaches.

\subsection{The Determinants of the Incidence of Fixed term Employment}

Most of the above mentioned models depart from a somewhat similar environ ment where firms face a revenue function $(R)$ which depends on labour $(N)$ being hired under two types of contracts, namely, permanent contracts $\left(N_{P}\right)$ and tem porary ones $\left(N_{T}\right)$, and possibly a shift factor $(Z)$ representing either different phases of the business cycle or a steady growth rate. It is further assumed that:

(i) output depends on a composite labour input through a production function with a constant elasticity of substitution $(\sigma)$ between $N_{P}$ and $N_{T}$

(ii) the efficiency of workers may vary depending on the contract under which they are hired

(iii) there is an iso elastic demand curve

(iv) the firm may offer both types of contract with wages $w_{P}$ and $w_{T}$, respectively

(v) termination of a permanent contract entails paying the worker a mandatory firing cost, $F$, whereas termination of temporary contracts involves no firing costs, and

(vi) firms are risk neutral and maximise the expected value of future profits taking into account adjustment costs in labour, denoted by $C(\Delta N)$.

Under these assumptions, the revenue function can be written as

$$
\begin{aligned}
R\left(Z, N_{P}, N_{T}\right) & =Z N^{\alpha} \\
N^{1-1 / \sigma} & =N_{P}^{1-1 / \sigma}+\left(\begin{array}{ll}
1 & m
\end{array}\right) N_{T}^{1-1 / \sigma} \quad \sigma>1
\end{aligned}
$$

so that, for a given demand shift factor, $Z$, and a relative efficiency of permanent workers, $1 /(1-m)$, the optimal choice of $N_{P}$ and $N_{T}$ implies that the ratio of temporary to permanent workers $\left(\phi=N_{T} / N_{P}\right)$ will be

$$
\phi(Z)=\left\{\left(\begin{array}{ll}
1 & m)
\end{array}\right) \frac{\left[w_{P}+X(Z)\right]}{w_{T}}\right\}^{\sigma}
$$

which is increasing in:

(i) the relative efficiency of permanent workers, $1 /(1-m)$

(ii) the relative wage, $w_{P} / w_{T}$

(iii) the elasticity of substitution, $\sigma$, and

(iv) the difference between the shadow value of a marginal worker and its wage, $X(Z)$.

In turn, firing costs, $F$, will affect the $\phi$ ratio through its effect on the shadow wage of permanent workers, $w_{P}+X(Z)$, as will be seen below.

The literature on dynamic labour demand with adjustment costs typically makes two further assumptions. First, that the shift factor, $Z$, represents two states of the economy: good $\left(Z_{G}\right)$ and bad $\left(Z_{B}\right)$, with $Z_{G}>Z_{B}$, and evolves as a 
symmetric Markov chain with probability $p$ from one state to the other so that, in the long run, both states have an equal probability of $1 / 2$. Second, ignoring for simplicity hiring costs in the analysis, that adjustment costs are linear and are given by $C\left(\Delta N_{P}\right)=-\left(\Delta N_{P}\right) F$ when $\Delta N_{P}<0$, and zero otherwise. Then, it follows that

$$
X\left(Z_{G}\right)=X_{G}=\frac{F p}{1+r}>0
$$

and

$$
X\left(Z_{B}\right)=X_{B}=\frac{F(p+r)}{1+r}<0
$$

where $r$ is the discount rate. As Bertola and Ichino (1995) have pointed out, the intuition for the expressions in (3) is that, in the good state, the firm does not need to fire this period but it will have to fire with probability $p$ next period (ie $\left.X\left(Z_{G}\right)=0+F p /(1+r)\right)$, whereas, in the bad state, if the firm keeps the permanent worker, it saves $F$ this period but then it faces dismissing the worker when the bad state remains next period, an event which occurs with probability $1-p$ (ie $\left.X\left(Z_{B}\right)=-F+F(1-p) /(1+r)\right)$. Hence, since the marginal revenue of hiring a permanent worker is below (above) its shadow wage in a bad (good) state, a standard result in this literature is that the existence of firing costs implies fewer job terminations in the bad state and less job creation in the good state, with lower inflows into and outflows from both employment and unemployment. To the ex tent that temporary jobs entail no redundancy pay, both their creation and de struction rates will be higher than those of permanent jobs in an upturn and a downturn, respectively. Thus, the ratio of temporary to permanent workers, $\phi$, will fall in good states and increase in bad states. However, the effects of firing costs on aggregate employment are ambiguous, since employment is moving in the opposite direction both across types of contract and states. For example, considering for simplicity the particular case in which there are no temporary contracts, $N_{P}=N$ $\left(N_{T}=0\right)$ and a linear marginal revenue function, ie $\partial R_{i}(,) / \partial N_{i}=Z_{i}-\beta N_{i}, i=$ $G, B$, one can obtain the well known conclusion derived by Bentolila and Bertola (1990) that a reduction in firing costs may reduce average employment. This is so since, under the symmetry assumption in the Markov chain, average employment will be given by to $1 / 2\left(N_{G}+N_{B}\right)$ and a reduction of one unit in $F$ increases $N_{G}$ by $p / \beta(1+r)$ while it decreases $N_{B}$ by $(r+p) / \beta(1+r)$. Hence average employment is reduced by $1 / 2 r / \beta(1+r)$. Obviously, for more general functional forms of the rev enue function than the one considered above, the previous result no longer holds and the effects of firing costs on average employment are ambiguous (Bertola, 1992). An unambiguous result, however, is that lower firing costs increase average profit across states. This can be easily seen from the previous example where profits are given by $Z N_{i} \quad 1 / 2 \beta N_{i}^{2} \quad\left(w_{\mathrm{P}}+X_{i}\right) N_{i}$, for which it can be easily proved that, when $F>0$, average profits decrease by $1 / 2\left(X_{G}\right)^{2}$ in the good state and by $1 / 2\left(X_{B}\right)^{2}$ in the bad state relative to the case where firing costs are null. This implies that when these partial equilibrium models are extended to include investment decisions by the firm, it is often the case that firing costs lead to lower investment which, in turn, 
decreases labour demand, for a given level of capital stock, inducing an employ ment reduction (Risager and Sorensen, 1997).

\subsection{Fixed term Contracts and Unemployment}

The effects of fixed term contracts on unemployment have also been analysed in several extensions of the basic search and matching framework (Pissarides, 1990) to the case of two types of contracts under different assumptions on the use of these contracts. One stream of this literature, assumes that firms can create both permanent contracts and fixed term contracts, the latter being necessarily ter minated when they expire, and that the separation rates $\left(s_{i}, i=P, T\right)$ for both types of workers are exogenous (typically $s_{P}<s_{T}$ ). Wasmer (1999) provides an interest ing model within this class, which focuses on the effects of exogenous productivity growth on labour market tightness (i.e. the ratio between the vacancy and the unemployment rates) and on the share of temporary jobs. The production side is similar to the one described above, except that that both types of labour are assumed to be perfect substitutes (ie $N=N_{T}+N_{P}$ ), and that $Z$ now represents an index of labour augmenting technical progress growing at rate $g$ for both kinds of jobs, so that $Z=\mathrm{e}^{g t}$ and $R=R\left(N \mathrm{e}^{g t}\right)$. Adding a further assumption about how workers rank vacancies in their job search (workers prefer to start searching for permanent jobs and, only in case of failure, then look for a temporary job) to the standard list of assumptions in this literature, ${ }^{7}$ it is possible to derive the three basic relations that characterise most matching models, namely, the job creation $(J C)$ and job destruction $(J D)$ schedules, which determine wages and labour market tightness, and the Beveridge curve $(B C)$ schedule, that determines the unemployment and vacancy rates for given tightness. In such a set up, it can be shown there is a threshold growth rate separating two regimes, one in which only permanent jobs exist, and another in which both jobs coexist. The intuition for that interesting result is the so called capitalisation effect whereby a higher growth rate increases future profits, through a lower discount rate, increasing labour tightness and hence enhancing the incentives of firms to offer permanent con tracts so as to retain workers. In terms of the $J C$ and $J D$ schedules, a rise in the growth rate of technical progress, $g$, shifts both curves upwards (leading to more creation and destruction of jobs) so that wages (as a proportion of the marginal productivity of labour) increase, whereas the effect on tightness is ambiguous. It can be shown that, if workers' bargaining power is not too high, the shift in the $J C$ curve dominates, so that tightness increases with growth. As for the $B C$ schedule, it will shift inwards since a higher rate of technical progress, $g$, by reducing the ratio of temporary to permanent workers, $\phi$, leads to a lower average separation rate. Hence, in the case where labour tightness increases, unemployment (and the duration of unemployment spells) falls while the effect on vacancies is ambiguous.

7 Those assumptions are:

(i) the existence of a constant-returns matching function relating hires to unemployment and vacancies

(ii) that firms face a flow cost of keeping vacancies unfilled, and

(iii) that workers and firms engage in generalised Nash-bargaining over wages. 
However, if workers' bargaining power is very high, the negative effect on em ployment of a higher wage pressure can overcome the increase in labour demand stemming from higher growth, implying that growth can increase unemployment. In sum, under the assumption that unions are not too powerful, the basic impli cation of this model is that, in periods of high growth, the proportion of temporary jobs will be smaller while the unemployment rate will drop for a similar level of vacancies. Conversely, the opposite happens when unions are very powerful.

Another stream of this literature, along the lines of Mortensen and Pissarides (1994), make the separation rates, $s_{i}$, endogenous by assuming that productivity depends on a match specific component, $x$, which comes from a given distribution, $G(x)$, that may change with the duration of the employment spell, so that there is an endogenously determined productivity threshold below which separations are triggered. An interesting illustration of this line of research is Cahuc and Postel Vinay (2001). ${ }^{8}$ In their model, firms can also open both types of vacancies, but the first period in a permanent contract is taken to be a qualifying or probationary one entailing no severance payment at its termination if the firm decides to destroy the job, while fixed term contracts, which are assumed to require the approval of the government, last for one period and, at their termination, the job is either des troyed or converted into a permanent one at its qualifying stage. Thus, there will be three interdependent productivity thresholds under which jobs are destroyed. In increasing order, those cut off values correspond to fully permanent jobs, fixed term contracts and probationary jobs, respectively, leading to three $J D$ schedules, one for each type of contract. The intuition for the previous ordering is that, at a given period, firms will be more reluctant to destroy permanent jobs than the other types of jobs since they have to pay a firing cost immediately, and less reluctant to destroy a probationary job than a fixed term contract since keeping them in the future entails having to pay firing costs next period in case of destruction for the former, whereas the severance pay will only take place two periods later for the latter. In this model, facilitating the use of fixed term contracts, by increasing their rate of approval, increases the three productivity thresholds and the overall tight ness in the labour market. However, the higher are firing costs, the larger is the rise in the productivity thresholds of the non fully permanent contracts relative to that of fully permanent contracts. Thus, if firing costs are sufficiently high, a less re strictive legislation on fixed term contracts, despite fostering job creation, might increase job turnover in the non permanent jobs by so much that it may end up leading to a rise in unemployment. In this respect, one of the main implications of this model is that trying to achieve a more flexible EPL through spreading fixed term contracts without a parallel reduction of high firing costs for permanent employees is bound to be an inefficient policy in terms of fighting unemployment.

\subsection{Fixed term Employment, Productivity and Wages}

Another relevant issue in the analysis of fixed term contracts is why they are used in jobs where stable labour relations are an important source of efficiency. For

\footnotetext{
${ }^{8}$ Blanchard and Landier (2002) provide a different model with somewhat similar implications.
} 
instance, this is the case where jobs require specific human capital investment for which the investment decision depends crucially on the expected duration of the job, or in other types of activities where the provision of incentives turns out to be important to increase workers' productivity. Efficiency wage models provide a natural framework to analyse these cases. Güell (2000) provides an interesting application of the shirking efficiency wage model to a labour market where firms can offer permanent contracts and fixed term contracts, which are allowed to be converted into permanent contracts at their termination. In that model, workers under both types of contract decide each period whether to shirk or not to shirk. As is standard in the literature, firms have a monitoring technology allowing them to identify whether a worker is shirking with a given probability. If found shirking, a permanent worker is dismissed and becomes unemployed whereas a temporary worker does not have his (or her) contract renewed. All workers also face an exogenous separation probability, $s$, which entitles them to receive a severance payment, $F$, if they are working under permanent contracts and nothing under fixed term contracts. Finally, only permanent workers who have suffered a disci plinary dismissal can sue the employers in court for disagreement and there is a probability, $p_{u}$, that the dismissal may be declared unfair. Hence the expected severance payment of a permanent worker caught shirking is $p_{u} F$. It is shown that, in the absence of fixed term contracts, if $p_{u}>s$, firing costs will be detrimental for employment. This is so because the incentive compatible wage is reduced by $s F$ (a wage moderating effect), ${ }^{9}$ since statutory firing costs compensate the worker being fired for non disciplinary reasons, while it is increased by the larger amount $p_{u} F$ (a wage enhancing effect), since the firm is forced to pay a higher wage so as to avoid shirking when it faces the possibility that a disciplinary dismissal may be declared unfair by the court. Interestingly, if $p_{u}$ is not too high, allowing for fixed term contracts can increase employment, as long as the renewal rate is sufficiently high so as to provide temporary workers with an incentive to avoid shirking. Thus, an important implication of this model is that, ceteris paribus, those countries where there is a vague distinction among the different types of dismissal will tend to have lower renewal rates and a higher proportion of fixed term contracts.

Along similar lines, it can be argued that fixed term contracts can have a positive effect on effort if workers perceive that the rehiring probability depends on past performance. Furthermore, if the rate of renewal is low, firms and workers may be less inclined to invest in specific human capital, implying that workers under fixed term contracts will tend to receive less training. Due to this hold up problem, firms might find it appropriate to pay some firing costs, albeit not too high, as a com mitment device to maintain a certain degree of job stability (Saint Paul, 1996). ${ }^{10}$

\footnotetext{
${ }^{9}$ This effect can be somehow interpreted in terms of Lazear's (1990) well-known argument whereby, in a competitive labour market with no frictions, the increase in labour costs for firms induced by statutory severance pay can be undone by a 'voluntary' transfer from the worker to the firm in the form of a private contract. In that contract, the worker will receive a lower wage while working and will be compensated by a higher income when dismissed. The usual problem with this private arrangement against the income risk associated to a job loss is that firms may have incentives to default on its obligations if bringing a defaulting firm to court entails high 'red tape' costs.

${ }^{10}$ In a similar vein, Booth (1997) also makes the point that, even in unionised sectors, if unions and firms bargain about both wages and redundancy pay, as opposed to just wages, average employment can increase.
} 
Finally, the introduction of fixed term contracts may also be relevant for wage determination, affecting the relative wage of permanent and temporary workers, $w_{P} / w_{T}$, in different ways. In particular, it can induce an increase of permanent workers' wages, as shown by several papers drawing from the extension of the insider outsider wage bargaining models. For instance, Bentolila and Dolado (1994) suggest that if unions are dominated by workers under permanent con tracts subject to high firing costs, and they set wages for all workers, then the existence of fixed term contracts increases their bargaining power. Thus, insofar as the existence of flexible jobs with no firing costs provides a buffer against the negative effect of wage rises on their employment probability, wages of permanent workers will be higher, the higher the share of fixed term contracts is. However, if firms can pay lower wages for employers under fixed term contracts, then that may compensate for the buffer effect and overall labour costs for the firm may not change or even decrease as the proportion of fixed term contracts increases.

\section{A Look at the (Spanish) Evidence}

Spain having been a pioneer at introducing 'two tier' labour market reforms, in the form of the dual system of work contracts discussed above, it is not surprising that it has become a typical case study for the search of empirical support on the main theoretical predictions surveyed in the previous section. In what follows, we summarise the main empirical findings drawn from the Spanish experience.

First, there is overwhelming evidence that fixed term contracts and lower firing costs increase the volatility of employment by rising both the hiring and layoff rates. García Serrano (1998) estimates temporary workers' and job quarterly flows of $57 \%$ and $11 \%$, respectively, against $2.6 \%$ and $1.6 \%$, respectively, for permanent workers. Likewise, García Serrano and Jimeno $(1999 a, b)$ find that a rise of 1 percentage point in the proportion of fixed term contracts increases the flows of employment to unemployment, unemployment to employment and employment to employment by $0.26,0.16$ and 0.34 percentage points, respectively, and reduces job tenure by $2.3 \%$, namely, by two months in a mean elapsed job tenure of nine years. $^{11}$

Second, insofar as the use of fixed term contracts implies a rise of the hiring rate, long term unemployment might have been reduced. Here the evidence is more mixed. On the one hand, the incidence of long term unemployment decreased a lot, from $67 \%$ in 1987 to $47 \%$ in 1992, during the period in which the share of fixed term contracts exploded from $15 \%$ to $33 \%$. Given the very limited use over that period of active labour market policies, the other main determinant of long term unemployment, it seems sensible to conclude that the outburst of fixed term contracts helped to achieve such a reduction. On the other, however, the inci dence of long term unemployment raised from $48 \%$ to $56 \%$ in the recession of the

\footnotetext{
11 On the effects of temporary employment on workers' flows, see also Saint-Paul (2000a) where it is shown that Spain has relatively small flows out of unemployment (comparable to France) while it has relatively large flows from employment into unemployment (of the same order of magnitude as in the USA).
} 
first half of the 1990 s, while it fell back to $45 \%$ at the subsequent upturn during the second half of that decade. One possible explanation of such different evolution is that, despite the fact that the availability of fixed term contracts has implied a significant increase in the average outflow rate, the higher employment chances have not been shared equally by all unemployed (Güell, 2001). In particular, those long term unemployed workers who became unemployed due to the termination of permanent contracts in their previous job seem to have had stronger duration dependence after 1984 than before since the frequent shifts from job to job by workers holding fixed term contracts may have crowded their employment pros pects. To the extent that, after the mid 1990s, the share of fixed term contracts has stabilised around $33 \%$ and that EPL on permanent contracts relative to fixed term contracts has been weaker, that adverse effect on the incidence of long term unemployment seems to have been overcome.

Third, some of the theoretical models discussed in Section 2 imply that the widespread use of fixed term contracts has, in principle, an ambiguous effect on the mean unemployment rate. However, if either wage setting or the firms' investment rate in physical capital is adversely affected by the existence of a dual labour market, then the unemployment rate might rise. On the one hand, there is empirical evidence regarding the adverse effects of fixed term contracts on wage pressure in Spain, to be discussed below, at least until the early 1990s when the median voter in the unions was a worker with a permanent contract. On the other hand, since the mid 1990s when the relative strictness of EPL regarding permanent and fixed term contracts was reduced, temporary contracts may have probably had a favourable effect on reducing hysteresis which, as pointed out by Dolado and Jimeno (1997), has been a major factor behind the rise and per sistence of the Spanish unemployment rate. As for the effects through invest ment, employment contracts with high firing costs in case of unfair dismissal which can be appealed to labour courts, may induce a higher level of uncertainty and, therefore, contribute to reduce firms' investment on physical capital. ${ }^{12}$ That effect can be partially responsible for the fall of the investment to GDP ratio, from an average value of $22.5 \%$ since the early 1970 s to values around $19.7 \%$ in the recessions of the 1980s and 1990s. Thus, overall, the decision on whether temporary contracts are good or bad for unemployment seems to be even depending on what period one looks at. However, the introduction in 1997 of the new permanent contracts with lower redundancy pay seems to have helped to reduce the unemployment rate from $20 \%$ in 1997 to $13.0 \%$ nowadays, in agreement with the implication drawn from Cahuc and Postel Vinay's (2002) model. Moreover, the small reduction in the share of temporary work after 1997 has taken place in a period of high growth where the bargaining power of the unions seems to have declined, in accord with the implications of Wasmer's (1999) model.

\footnotetext{
12 The relevance of uncertainty can be grasped by the fact that employers, so as to avoid a lengthy process and large 'red tape' costs associated to the arbitration procedure, tend to avoid dismissal procedures by reaching pre-trial agreements involving higher redundancy payments than those legally established (Malo, 2000).
} 
Fourth, a rise in the turnover rate decreases the probability of investing in specific human capital or receiving specific training in the firms and, therefore, may decrease labour productivity. This is particularly so, if the conversion rate of fixed term contracts into permanent contracts is low, reflecting the fact that employers use those contracts more as a flexible device to adjust employment in the face of adverse shocks than as a screening device under asymmetric infor mation. Güell and Petrongolo (2000) analyse the duration pattern of fixed term contracts and the determinants of the probability of their transformation into permanent contracts, which went down from $18 \%$ in 1987 to about $5 \%$ in 1996 , finding two very pronounced spikes in this probability at one and three years of duration of fixed term contracts, the latter coinciding with the maximum legal duration before 1994. The first spike can be explained by employers' using fixed term contracts as a screening device and applies mostly to skilled workers, whereas the second spike just reflects their use as a more flexible alternative for adjusting employment.

With such a low conversion rate, it is not surprising that investment in on the job training seems to be negatively affected by fixed term effects. Dolado et al. (1999) estimate that the probability of receiving free or subsided on the job training in 1994 was $22 \%$ lower for workers under fixed term contracts than for workers under permanent contracts. The fact that under investment in specific human capital has strong implications about overall labour productivity is clearly illustrated by the cyclical upturn of the late 1980s, where employment growth was based on the massive use of fixed term contracts and labour productivity hardly reached an annual average growth rate of $1 \%$ during the 19861990 upturn. Likewise, labour productivity growth has been low during the 19972000 upturn. Finally, the results in Jimeno and Toharia (1996) also suggest that temporary employment increases work accidents, which happen to be three times larger for workers under fixed term contracts than for workers under permanent contracts.

Fifth, as for the effects on wages, the discussion at the end of Section 2 indicates that an increased dualism in the labour market may imply a higher wage pressure if the unions protect the interests of permanent workers in the wage bargaining. In this respect, Bentolila and Dolado (1994), using a large panel data on firms over the 19848 period, find that an increase of 1 percentage point in the temporary employment share raises the growth rate of permanent workers' wages by about $0.3 \%$. An alternative effect of fixed term contracts on wages arises from the existence of a negative wage differential for workers under these contracts relative to workers under permanent contracts. Although, in principle, wage rates cannot be differentiated by type of contract, some empirical studies find that, after con trolling for observed and unobserved heterogeneity in personal and job related characteristics, permanent workers earn around $10 \%$ to $15 \%$ more, for men, and about 7\%, for women; see, for instance, Jimeno and Toharia (1993) and Davia and Hernanz (2000). The previous evidence also points out that the wage gap is associated with the fact that employers tend to 'under classify' temporary workers in the occupational categories probably to cut total labour costs in view of the higher wage pressure on permanent contracts described above. Therefore, although temporary workers may be doing a similar job, their wages are lower that 
those of similar workers with permanent contracts. ${ }^{13}$ Insofar as higher educated workers are more prone to under classification than lower educated workers, that process should lead to a widening of the wage (earnings) distribution for the former group of workers. Bover et al. (2000) support this conjecture by finding that the ratio between the 75 th and the 25 th percentiles of the distribution of $(\log )$ earnings of workers with tertiary education increased by $8 \%$ during the 1980 s, while the corresponding ratio for lower educated workers hardly changed.

Finally, higher worker turnover leads to larger uncertainty and therefore fixed term contracts may hinder labour mobility and reduce fertility rates. As for labour mobility, absolute net inter regional migration has almost halved between the 1960s and the 1990s (Bentolila, 1997) and only about $30 \%$ of the unemployed would accept a temporary job implying a change of residence. As for demographic effects, both high unemployment and employment instability are found to be two of the most relevant factors behind the decline in the fertility rate which fell from almost 3 in the late 1960s, to around 1.2 nowadays (Ahn and Mira, 2001).

On the whole, the Spanish evidence on the labour market effects of temporary contracts seems to support the following main theoretical predictions:

(a) a large increase in workers' turnover

(b) a reduction in long term unemployment when the relative strictness of EPL regarding permanent and fixed term contracts is reduced

(c) a fall in investment on specific human capital and a decrease in labour productivity

(d) a decline in regional migrations and in the fertility rate

(e) a widening of the wage distribution for higher educated workers

(f) a neutral or slightly positive effect on unemployment, particularly after the 1997 reform.

\section{The Resilience of the Proportion of Temporary Jobs}

The recent evolution of fixed term contracts in Spain may suggest that once these contracts become entrenched in the labour market, it may prove difficult to reduce its incidence. As discussed in Section 1, over the 1990s, there has been a change of emphasis in the objectives of labour market reforms regarding EPL towards reducing the incidence of fixed term contracts. Probably the most im portant reform was the one in 1997 when the new permanent contract with lower firing cost was introduced. After four years, this policy reversal seems to have been fairly successful. In combination with an upturn in the business cycle, 1.5 million jobs have been created, of which $76 \%$ correspond to workers under permanent contracts. This evolution contrasts sharply with the one observed at the previous upturn of the late 1980s where most of the employment created at the time was of

\footnotetext{
13 Indeed, as pointed out by Booth et al. (2002), the theory of 'compensating differentials' would imply that workers of the same characteristics would only prefer a temporary contract to a permanent one if compensated in wage terms for the loss of the option to remain in the job. However, as also pointed out by those authors, the wage of temporary workers might be lower if they have no incentive, given the low renewal rate, to invest heavily on specific human capital.
} 
temporary nature and permanent employment even fell. However, the proportion of workers under fixed term contracts still remains around $32 \%$, albeit with a different evolution across population groups. In effect, the proportion of tem porary employment has fallen by 6.4 percentage points for youth workers aged less than 25, although it remains at $68 \%$, well above $25 \%$ for adults. More significantly, the incidence of temporary jobs in the private sector has dropped by 4 percentage points reaching $35.3 \%$ in 2000 , a reduction which has been partially offset by the rise of the incidence of temporary work in the public sector, where it has reached $19.5 \%$, after increasing by 3.9 percentage points over the period. ${ }^{14}$

Since the evolution of temporary work in the public sector seems to be re sponsible for the small decline of the overall share since the mid 1990s, it is useful to take even a closer look at the disaggregated data for that sector. Fig. 4 depicts the incidence of temporary workers in the private sector and in the public sector, distinguishing among three levels of administration (central, regional and local) and public firms. In contrast with the declining trend observed since 1997 in the private sector, the proportion of temporary workers has increased in the public sector, notably in Local Governments and in Public Enterprises.

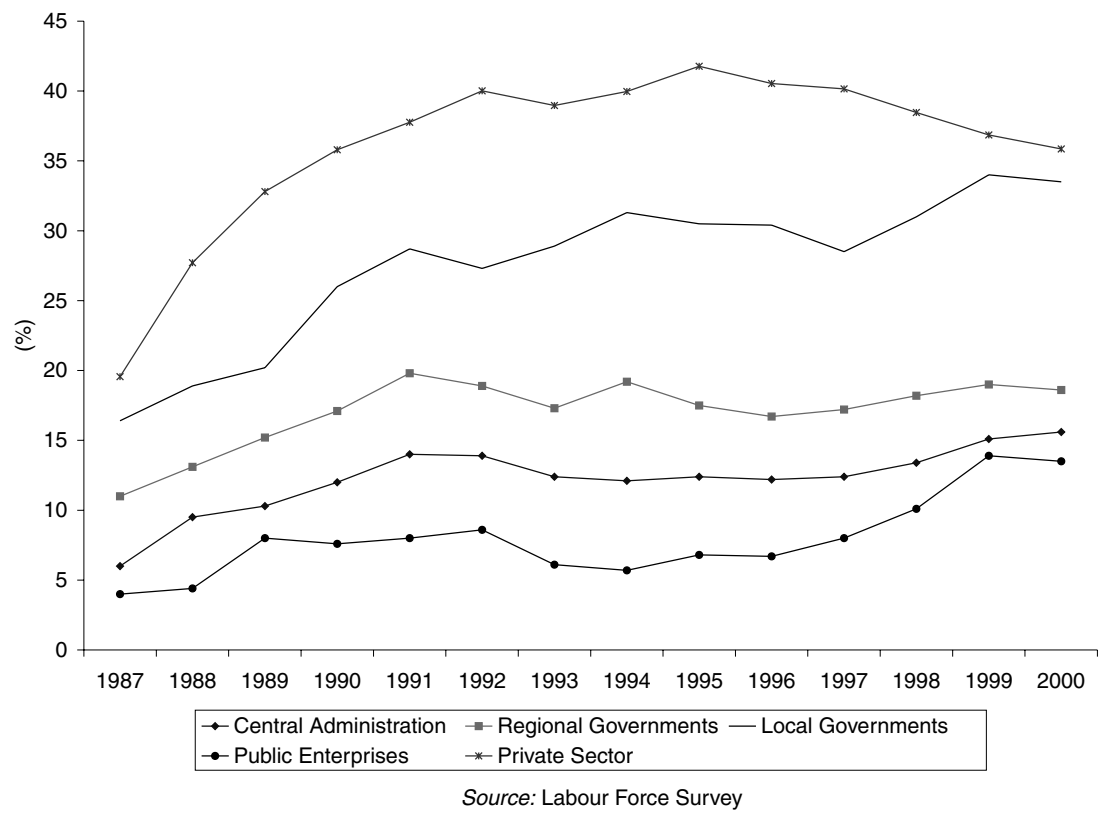

Fig. 4. Proportion of Temporary Workers in the Private Sector and in the Public Sector by Level of Administration, Spain, 19872000

14 Nevertheless, the average number of temporary contracts per job has risen from 2.9 in 1997 to 3.5 in 2000 , since most of the temporary contracts converted into permanent ones were those with long duration between 10 and 30 months. 
To have a better empirical understanding of the recent evolution of the incidence of temporary jobs in terms of the evolution of its various determinants, we perform two empirical exercises:

(i) the estimation of a regression model with sectoral and regional data

(ii) the estimation of a probit model with individual data.

As for the first exercise, we rely on (2) in Section 2 and estimate a regression model in which the logistic transformations of the proportion of temporary employment in total employment $(l \tau),{ }^{15}$ is modelled as a function of industry, regional and time dummies, and a set of industry and regional covariates:

$$
l \tau_{i j t}=\lambda_{i}+\lambda_{j}+\mu_{t}+\beta Z_{i j t}+\varepsilon_{i j t}
$$

where $i(=1,2 \ldots 17)$ stands for region, $j(=1,2 \ldots 17)$ stands for sector, $t(=1987, \ldots 2000)$ stands for year; $\lambda_{i}, \lambda_{j}$ and $\mu_{t}$ are, respectively, regional, industry and time fixed effects, $Z_{i j}$ is the set of covariates, and $\varepsilon_{i j t}$ is an iid error term. The set of covariates includes:

(i) the rate of growth of regional employment to control for the business cycle ${ }^{16}$

(ii) the proportion of young (under 25 years of age) workers in each region/ sector, since youth are likely to be more affected by temporary contracts than adult workers

(iii) the proportion of employees in each region/sector with a university degree

(iv) the proportion of employees in each region/sector covered by collective bargaining

(v) the proportion of public employees in each region/sector, to test for the possible lower propensity of the public sector to hire workers under tem porary contracts, and

(vi) and (vii) the latter two variables interacted with a time dummy variable for the period 19982000 to check whether there has been a regime shift in the behaviour of those variables after the 1997 reform. ${ }^{17}$

Variable (i) is a proxy for business cycle fluctuations, while variables (ii) to (v) should capture the effects of the wage gap between permanent and temporary workers, the elasticity of substitution and the relative efficiency of temporary contracts. On the one hand, we expect the wage gap to be inversely related to the proportion of employees working in the public sector, since they are likely to be less discriminated against. On the other hand, the wage gap is expected to be positively correlated both with the proportions of young and highly educated workers since the possibility of occupational 'under classification' may be larger for those groups. Finally, variables (vi) and (vii) are included to test both for the

${ }^{15}$ The logistic transformation is used to extend the support of the dependent variable to the whole real line.

${ }^{16}$ Since we introduce time dummies in the regression, regional employment growth captures the deviation of the business cycle across regions.

17 The total number of observations, after disregarding empty cells, is 4017 for 288 regional industries. The data set is constructed from information provided by the Labour Force Survey and by the Spanish Ministry of Employment. 
differential hiring patterns of the public and private sectors and for the role of collective bargaining after the 1997 reform.

Table 1 reports the OLS estimates for two alternative definitions of the dependent variable: the proportion of employees under all types of temporary contracts (column 1) and the proportion of workers under fixed term contracts (column 2). The results are very similar in both cases. Both shares are higher for young workers and lower for public sector workers, while the proportion of graduates is not significant. The estimated coefficient on the proportion of union coverage is negative indicating that the wage pressure in favour of permanent contracts has provoked a labour adjustment in firms though the termination of temporary contracts in those regions/sectors where unions are more powerful. This effect, however, is weaker after the 1997 reform. Most importantly, the in teraction of the 19982000 time dummy with the share of public employment has a very significant positive effect, indicating that the negative effect of the hiring practices of the public sector on the incidence of temporary work has decreased by 0.3 percentage points since the 1997 reform. This result seemingly confirms our conjecture about the key role played by the public sector in explaining the per sistence of share of temporary work during the late 1990s.

The second exercise entails the estimation of a model determining the prob ability of being employed under fixed term contracts in both the private and the public sector over the period 1990 2001. The sample includes all individuals aged 1644 years who are either employed or unemployed, excluding those out of the

Table 1

Estimates of the Determinants of the Proportion of Temporary and Fixed term Employment across Sectors and Regions. Spain, 19872000

\begin{tabular}{lcc}
\hline \hline & $\begin{array}{c}(1) \text { Dependent variable: } \\
\text { Proportion of temporary } \\
\text { employees }\end{array}$ & $\begin{array}{c}\text { (2) Dependent variable: } \\
\text { Proportion of fixed-term } \\
\text { employees }\end{array}$ \\
\hline Proportion of public employees & 0.006 & 0.005 \\
& $(4.52)$ & $(3.62)$ \\
Proportion of young employees & 0.039 & 0.034 \\
& $(16.94)$ & $(13.07)$ \\
Proportion of employees with a university & 0.003 & 0.002 \\
degree & $(1.49)$ & $(0.92)$ \\
Proportion of employees covered by & 0.001 & 0.001 \\
collective bargaining within the region & $(0.55)$ & $(0.99)$ \\
Proportion of employees covered by & 0.006 & 0.004 \\
collective bargaining & $(2.07)$ & $(2.12)$ \\
Rate of growth of regional employment & 0.010 & 0.010 \\
& $(3.08)$ & $(2.71)$ \\
Proportion of employees covered by & 0.002 & 0.001 \\
collective bargaining $\times$ dummy 1998-2000 & $(1.37)$ & $(1.51)$ \\
Proportion of public employees $\times$ dummy & 0.003 & 0.003 \\
1998-2000 & $(3.94)$ & $(4.21)$ \\
$\mathrm{R}^{2}$ & 0.70 & 0.66 \\
$N$ & 4,017 & 4,017 \\
\hline \hline
\end{tabular}

Note: The regression model also contains time, regional and industry fixed effects. Robust unsigned t-statistics in parenthesis. 
labour force. ${ }^{18}$ Our specification includes age dummies, gender, educational attainment levels, dummies for occupations and industrial sectors, the rate of growth of regional employment distinguishing among agriculture, manufactur ing, construction, and service sectors and time dummies, both separately and interacted with the rest of the covariates. We also control for the selectivity bias of being an employee under a fixed term contract in either the private or public sectors through Heckman's lambda method. The selection equations determining employment in each sector include age dummies, gender, educational attainment levels, and household status (breadwinner, spouse, living with parents etc.). For the time dummies, we distinguish three periods corresponding to the different regimes in the regulation of fixed term contracts over the last decade: 1990 94, 1995 7, 1998 2001. The latter dummy variable is intersected with age, education, sector and type of job since, as in the previous exercise, our main interest is to estimate how the 1997 reform has affected the probability of being employed under fixed term contracts for various population groups. The estimated coeffi cients and their t statistics are reported in Tables A1 and A2 of the Appendix, while Fig. 5 plots the corresponding estimated probabilities of being employed under a fixed term contract in the private and public sectors for some specific individual and job characteristics. It should be noted that there is strong evidence of selec tivity bias (ie the coefficients on Heckman's lambda are very significant and pos itive) indicating that those workers which are more prone to work in a given sector have a larger propensity to be hired under fixed term contracts in that sector. The results show a significant reduction of the probability of being employed under temporary contracts in the private sector (see Table A1) after 1997 for workers in the service sector, with secondary education, and performing manual skill jobs. Interestingly, for workers aged 30 44, who were excluded from the reduction of firing costs and the entitlement to employment subsidies, the probability of being employed under temporary contracts increases after 1997. As for the public sector (see Table A2), there is an overall increase in the probability of being hired under temporary contracts, particularly for unskilled workers in manufacturing and ser vice sectors. $^{19}$

As for why the public sector has increased so much the proportion of temporary hires in recent years, there are at least two explanations. First, following the fiscal consolidation pursued by the Spanish government after the Maastricht Treaty and the further restrictions imposed by the Growth and Stability Pact, limits have been imposed on the hiring of permanent workers so that for every four retirements in the Public Administration only one new permanent contract was allowed to be made. This change in the hiring behaviour of the public sector can be explained by the fact that the restrictions to workers' mobility and firings are much stricter in the public sector than in the private sector and the effort to reduce the size of the former sector are facilitated by the use of the more flexible temporary contracts.

\footnotetext{
18 The total number of observations is 641,335 and corresponds to a time series of cross-sections drawn from the information contained in the second quarters of the Labour Force Survey.

${ }^{19}$ For a complementary piece of evidence on the effects of the recent reform, see Kugler et al. (2001) who analyse the flows from unemployment to employment and from temporary employment to permanent employment distinguishing by population groups subject to different firing costs and entitled to dissimilar employment subsidies.
} 


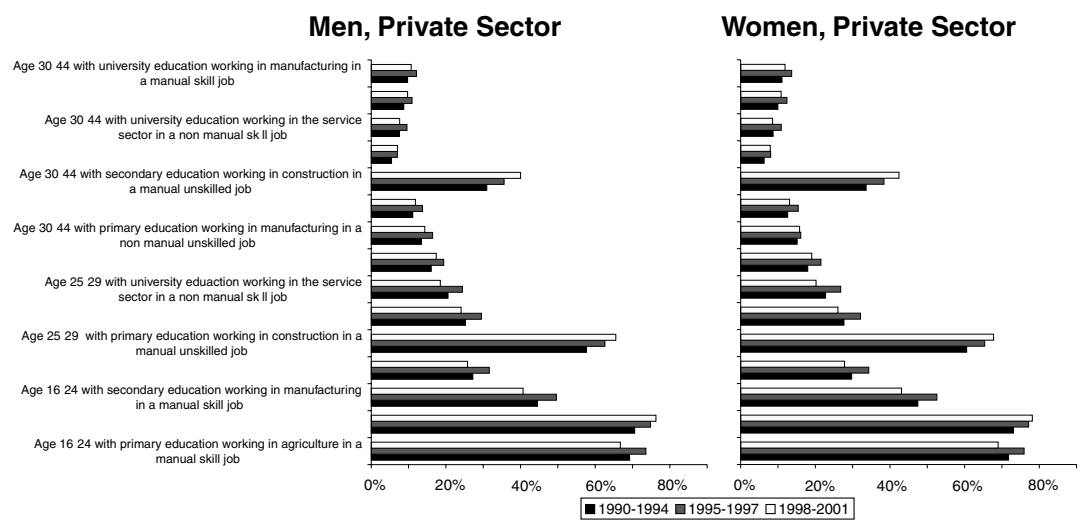

Men, Public Sector

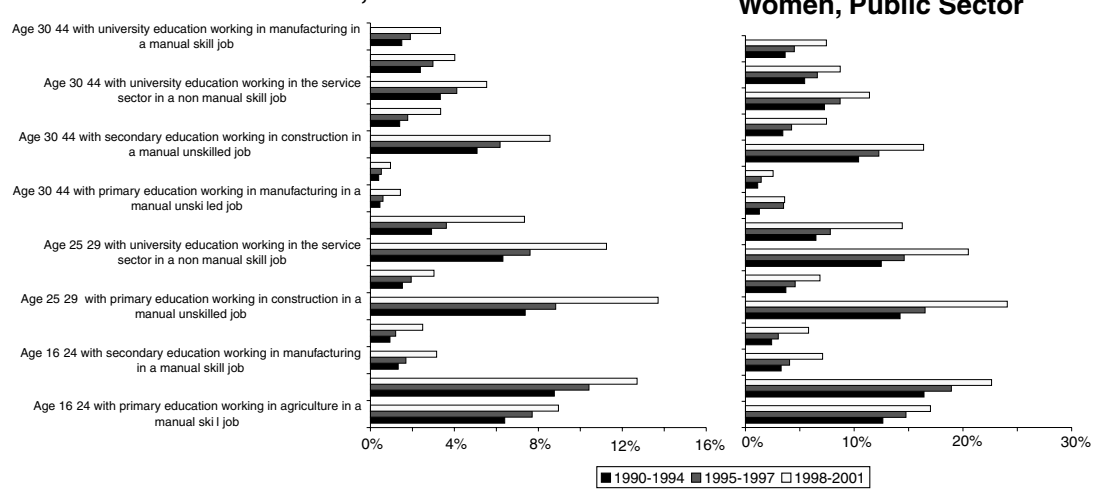

Fig. 5. Estimated Probabilities of being Employed under a Temporary Contract, Spain, 19902001

Second, a high proportion of the EC Structural Funds received by the Local Administrations for promoting active labour market policies (ALMPs), following the 1997 Amsterdam summit, have been used to hire workers in targeted groups (youth, female, long term unemployed etc.) under temporary contracts. Fig. 6 displays the correlation between the (log) temporary employment in the public sector in each of the 16 regions in Spain, ${ }^{20}$ as of 2000, and the $(\log )$ of the ALMPs funds allocated to each region by the European Social Fund (each normalised by total regional employment). The estimated coefficient in this regression is around $0.2(\mathrm{t}$ ratio $=3.4)$, so that an increase of $1 \%$ in those funds increases temporary employment in the public sector by $0.2 \%$. Further, if we eliminate the clear outlier, which corresponds to Catalonia, the estimated coefficient remains the same while the $t$ ratio rises to $4.3 .^{21} \mathrm{~A}$ benevolent interpretation of that result is that, insofar as

20 The Basque Country is excluded due to lack of data on ALMP funds.

${ }^{21}$ Catalonia represents an outlier because some of the ALMP funds are devoted to occupational training and that region makes intensive use of them. 


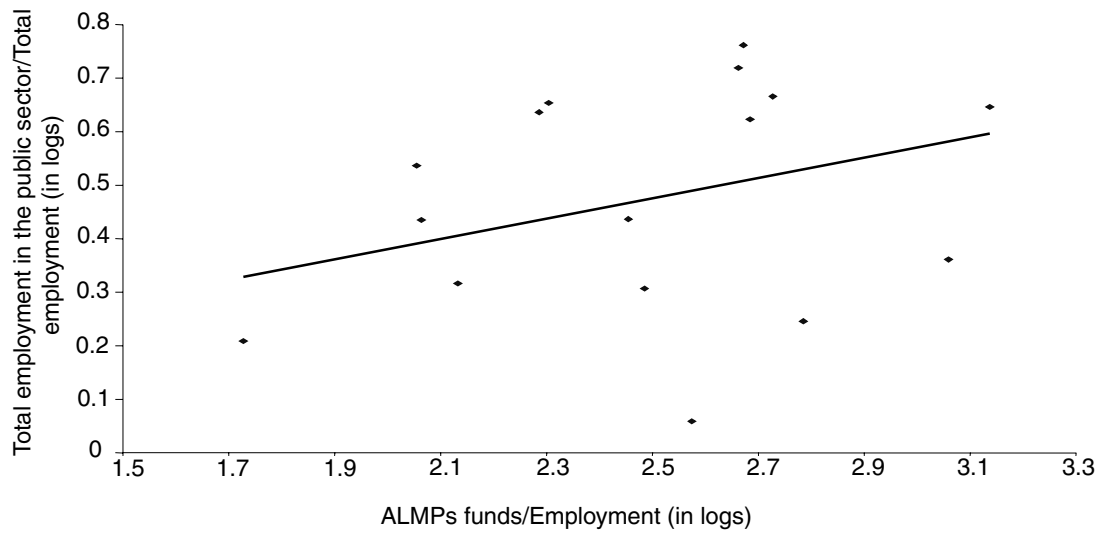

Fig. 6. Temporary Employment in the Public Sector and ALMPS Funds

jobs financed by ALMPs funds are mostly created for groups of workers with specific difficulties in the labour market, these temporary contracts, instead of being a pure flexibility device, may act as 'stepping stones' which can improve the 'employability' of those workers in the future.

\section{Concluding Remarks}

Since 1984, Spain has had the highest incidence of temporary employment in the EU, particularly in terms of fixed term contracts, although, since the mid 1990s, there has been a policy reversal towards reducing its scope. Recently, other EU countries (notoriously Italy and France) seem to have embraced the Spanish strategy of relaxing EPL by liberalising and promoting fixed term employment. According to our review of the Spanish experience, it cannot be taken for granted that this strategy improves the working of the labour market. Together with the plausible benefits of higher 'flexibility', there may be perverse effects on both efficiency and equity grounds. In principle, the most evident effects of the surge of temporary employment are higher worker and job turnover rates, and lower un employment duration for those workers holding fixed term contracts. As regards the unemployment rate, the evidence is more mixed. On the one hand, the lower firing costs associated with fixed term contracts seem to have contributed to employment growth. Yet, on the other hand, there have been some unexpected negative consequences stemming from the existence of a segmented/dual labour market such as lower investment in human capital, higher wage pressure, a more unequal distribution of unemployment duration, lower labour mobility and fer tility rates and larger wage dispersion.

In fact, a symptom on the mixed blessings of temporary employment is the policy reversal regarding EPL reforms which has taken place in Spain since the mid 1990s with the aim of reducing the proportion of temporary employment by lowering firing costs under the permanent contracts and subsidising both hires 
under permanent contracts and the conversion of temporary contracts into per manent ones by means of rebates of Social Security contributions. The preliminary evidence presented in Section 4 shows that, as a result of these measures, the incidence of temporary employment in the private sector has fallen by about 4 percentage points, although the aggregate rate has only dropped by about 1 percentage point because of the increase of temporary employment in the public sector. Thus, there are two topics that deserve further research. First, the relative contribution of lower firing costs under permanent contracts and of social security rebates to the reduction of the proportion of temporary employment in the private sector remains to be estimated. Second, the public sector behaviour regarding the use of temporary employment as a means to provide active labour market policies needs to be further scrutinised.

Universidad Carlos III and CEPR.

Universidad de Alcalá.

Universidad de Alcalá, FEDEA and CEPR.

Table A1

Probit Estimation with Sample Selection

\begin{tabular}{|c|c|c|}
\hline & Coefficient & t-stat. \\
\hline \multicolumn{3}{|l|}{ Probit model: Temporary employee in the private sector $=1$} \\
\hline Constant & 0.252 & 9.5 \\
\hline Age $25-29$ & 0.468 & 46.2 \\
\hline Age 30-44 & 1.083 & 92.8 \\
\hline Female & 0.074 & 10.5 \\
\hline Secondary education & 0.076 & 11.2 \\
\hline University education & 0.154 & 15.5 \\
\hline Manufacturing & 0.564 & 40.2 \\
\hline Construction & 0.120 & 8.6 \\
\hline Services & 0.394 & 29.5 \\
\hline Non manual unskilled job & 0.077 & 7.6 \\
\hline Manual skill job & 0.308 & 27.4 \\
\hline Manual unskilled job & 0.347 & 30.2 \\
\hline Rate of growth of agricultural employment & 1.461 & 7.9 \\
\hline Rate of growth of manufacturing employment & 0.308 & 3.5 \\
\hline Rate of growth of employment in construction & 1.177 & 17.8 \\
\hline Rate of growth of employment in the service sector & 1.544 & 7.1 \\
\hline Dummy 1995-1997 & 0.124 & 12.0 \\
\hline Dummy 1998-2001 & 0.002 & 0.1 \\
\hline Age $25-29 \times$ Dummy 1998-2001 & 0.055 & 4.5 \\
\hline Age $30-44 \times$ Dummy 1998-2001 & 0.135 & 12.3 \\
\hline Female $\times$ Dummy 1998-2001 & 0.012 & 1.3 \\
\hline Secondary education $\times$ Dummy 1998-2001 & 0.042 & 3.6 \\
\hline University education $\times$ Dummy $1998-2001$ & 0.023 & 1.5 \\
\hline Manufacturing $\times$ Dummy 1998-2001 & 0.013 & 0.6 \\
\hline Construction $\times$ Dummy 1998-2001 & 0.023 & 1.0 \\
\hline Service sector $\times$ Dummy 1998-2001 & 0.116 & 5.3 \\
\hline Non manual unskilled job $\times$ Dummy $1998-2001$ & 0.057 & 3.7 \\
\hline Manual skill job $\times$ Dummy $1998-2001$ & 0.078 & 4.7 \\
\hline Manual unskilled job $\times$ Dummy 1998-2001 & 0.165 & 9.7 \\
\hline Lambda & 0.780 & 30.0 \\
\hline$N$ & \multicolumn{2}{|c|}{641,096} \\
\hline
\end{tabular}


Table A1

(continued)

\begin{tabular}{lrr}
\hline \hline & Coefficient & t-stat. \\
\hline Selection equation: Employee in the private sector =1 & \\
Constant & 0.263 & 42.5 \\
Age 25-29 & 0.096 & 19.8 \\
Age 30-44 & 0.143 & 28.7 \\
Female & 0.127 & 31.5 \\
Secondary education & 0.001 & 0.4 \\
University education & 0.245 & 53.0 \\
Non-married breadwinner & 0.118 & 15.1 \\
Spouse & 0.252 & 44.2 \\
Living with parents & 0.217 & 44.8 \\
Other & 0.124 & 13.0 \\
$N$ & & 641,096 \\
\hline \hline
\end{tabular}

Sample: Employees, self-employees and unemployed, 30-44 years of age, 1990-2001.

Table A2

Probit Estimation with Sample Selection

\begin{tabular}{|c|c|c|}
\hline & Coefficient & t-stat. \\
\hline \multicolumn{3}{|l|}{ Probit model: Temporary employee in the public sector $=1$} \\
\hline Constant & 1.561 & 26.4 \\
\hline Age $25-29$ & 0.135 & 7.3 \\
\hline Age 30-44 & 0.440 & 17.7 \\
\hline Female & 0.378 & 37.9 \\
\hline Secondary education & 0.117 & 7.1 \\
\hline University education & 0.605 & 30.6 \\
\hline Manufacturing & 0.814 & 17.3 \\
\hline Construction & 0.042 & 0.9 \\
\hline Services & 0.449 & 11.6 \\
\hline Non manual unskilled job & 0.146 & 11.7 \\
\hline Manual skill job & 0.027 & 1.7 \\
\hline Manual unskilled job & 0.194 & 11.4 \\
\hline Rate of growth of agricultural employment & 0.171 & 0.6 \\
\hline Rate of growth of manufacturing employment & 0.715 & 4.7 \\
\hline Rate of growth of employment in construction & 0.205 & 1.8 \\
\hline Rate of growth of employment in the service sector & 0.668 & 1.8 \\
\hline Dummy 1995-1997 & 0.134 & 7.6 \\
\hline Dummy 1998-2001 & 0.256 & 3.2 \\
\hline Age $25-29 \times$ Dummy 1998-2001 & 0.032 & 1.2 \\
\hline Age 30-44 × Dummy 1998-2001 & 0.044 & 1.7 \\
\hline Female $\times$ Dummy 1998-2001 & 0.011 & 0.7 \\
\hline Secondary education $\times$ Dummy 1998-2001 & 0.011 & 0.4 \\
\hline University education $\times$ Dummy $1998-2001$ & 0.012 & 0.4 \\
\hline Manufacturing $\times$ Dummy 1998-2001 & 0.192 & 2.3 \\
\hline Construction $\times$ Dummy 1998-2001 & 0.108 & 1.2 \\
\hline Service sector $\times$ Dummy $1998-2001$ & 0.166 & 3.0 \\
\hline Non manual unskilled job $\times$ Dummy 1998-2001 & 0.007 & 0.3 \\
\hline Manual skill job $\times$ Dummy 1998-2001 & 0.028 & 1.0 \\
\hline Manual unskilled job $\times$ Dummy 1998-2001 & 0.008 & 0.3 \\
\hline Lambda & 1.270 & 36.1 \\
\hline$N$ & \multicolumn{2}{|c|}{641,335} \\
\hline
\end{tabular}


Table A2

(continued)

\begin{tabular}{lrr}
\hline \hline & Coefficient & t-stat. \\
\hline Selection equation: Employee in the public sector = & & \\
Constant & 2.157 & 225.1 \\
Age 25-29 & 0.273 & 35.5 \\
Age 30-44 & 0.651 & 87.0 \\
Female & 0.148 & 26.1 \\
Secondary education & 0.523 & 82.7 \\
University education & 1.242 & 190.0 \\
Non-married breadwinner & 0.082 & 8.8 \\
Breadwinner's spouse & 0.039 & 5.4 \\
Living with parents & 0.309 & 48.9 \\
Other household status & 0.150 & 11.4 \\
$N$ & & 641,355 \\
\hline \hline
\end{tabular}

Sample: Employees, self-employees and unemployed, 30-44 years of age, 1990-2001.

\section{References}

Ahn, N. and Mira, P. (2001). 'Job bust, baby bust: evidence from Spain', Journal of Population Economics, vol. 14(3), pp. 505-21.

Bentolila, S. (1997). 'Sticky labor in Spanish regions', European Economic Review, vol. 41, pp. 591-8.

Bentolila, S. and Bertola, G. (1990). 'Firing costs and labour demand: how bad is Eurosclerosis?', Review of Economic Studies, vol. 57, pp. 381-402.

Bentolila, S. and Dolado, J. J. (1994), 'Labour flexibility and wages: lessons from Spain', Economic Policy, vol. 18, pp. 55-99.

Bertola, G. (1992). 'Labor turnover costs and average labor demand', Journal of Labour Economics, vol. 10, pp. 389-411.

Bertola, G. and Ichino, A. (1995). 'Wage inequality and unemployment: US vs. Europe', NBER Macroeconomics Annual, pp. 13-54.

Blanchard, O. and Landier, A. (2002). 'The perverse effects of partial labor market reform: fixed duration contracts in France', ECONOMIC JOURnal, this issue.

Booth, A. (1997). 'An analysis of firing costs and their implications for unemployment policy' Chapter 12 in (D. Snower and G. de la Dehesa, eds.) Unemployment Policy : Government Options for the Labour Market, Cambridge: Cambridge University Press.

Booth, A., Francesconi, M. and Frank, J. (2002). 'Temporary jobs: stepping stones or dead-ends?', ECONOMIC JOURNAL, this issue.

Bover, O., Bentolila, S. and Arellano, M. (2000). 'The distribution of earnings in Spain during the 1980s: the effect of skill, unemployment and union power', Banco de España, Working Paper 0015, forthcoming in ECONOMIC JOURNAL.

Cahuc, P. and Postel-Vinay, F. (2002). 'Temporary jobs, employment protection and labour market Performance', Labour Economics (forthcoming).

Davia, M. A. and Hernanz, V. (2000). 'Fixed-term employment contracts and segmentation in the Spanish (youth) labor market', Universidad de Alcalá, mimeo.

Dolado, J. J. and Jimeno, J. F. (1997). 'The causes of Spanish unemployment: a structural VAR approach', European Economic Review, vol. 41, pp. 1281-307.

Dolado, J. J., Felgueroso, F. and Jimeno, J. F. (1999). 'Los problemas del mercado de trabajo juvenil en España: empleo, formación y salarios mínimos', Ekonomiaz, vol. 43, pp. 136-57.

García Serrano, C. (1998), 'Worker turnover and job reallocation: the role of fixed-term contracts', Oxford Economic Papers, vol. 50, pp. 709-25.

García-Serrano, C. and Jimeno, J. F. (1999a), 'Labour reallocation, labour flows and labour market institutions', CEP Discussion Paper no. 414, CEP, London.

García-Serrano, C. and Jimeno, J. F. (1999b). 'Job tenure and labour market institutions: lessons from Spain', Universidad de Alcalá, mimeo.

Güell, M. (2000). 'Fixed-term contracts and unemployment: an efficiency wage analysis', Princeton University, IRS working paper no. 433.

Güell, M. (2001). 'Fixed-term contracts and the duration distribution of unemployment', mimeo. 
Güell, M. and Petrongolo, B. (2000). 'Workers' transitions from temporary to permanent employment: the Spanish case', CEP, Discussion Paper 438.

Jimeno, J. F., and Toharia, L. (1993). 'The effects of fixed-term employment on wages: theory and evidence from Spain', Investigaciones Economicas, vol. 17(3), pp. 475-94.

Jimeno, J. F. and Toharia, L. (1994). Unemployment and Labour Market Flexibility: Spain, Geneva: International Labour Office.

Jimeno, J. F., and Toharia, L. (1996). 'Effort absenteeism, and fixed-term employment contracts', Revista Española de Economía, vol. 13(1), pp. 105-19.

Kugler, A., Jimeno, J. F. and Hernanz, V. (2001). 'Labour market consequences of restrictive permanent contracts: evidence from labour market reforms in Spain', work in progress.

Lazear, E. (1990). 'Job security provisions and employment', Quarterly Journal of Economics, vol. 105, pp. 699-726.

Malo, M. A. (2000). 'A simple model of severance pay determination: the case of individual dismissals in Spain', Labour, vol. 14, pp. 269-90.

Mortensen, D. and Pissarides, C. (1994). 'Job creation and job destruction in the theory of unemployment', Review of Economic Studies, vol. 64, pp. 397-415.

Pissarides, C. (1990). Equilibrium Unemployment Theory, Oxford: Basil Blackwell.

Risager, O. and Sorensen, J. R. (1997). 'On the effects of firing costs when investment is endogenous: an extension of a model by Bertola', European Economic Review, vol. 41, pp. 1343-53.

Saint-Paul, G. (1996). 'On the political economy of labor market flexibility', NBER Macroeconomics Annual, vol. 8, pp. 151-96.

Saint-Paul, G. $(2000 a)$. 'Flexibility versus rigidity: does Spain have the worst of both worlds', IZA, Discussion Paper no. 144.

Saint-Paul, G. (2000b). The Political Economy of Labor Market Reforms, Oxford: Oxford University Press.

Wasmer, E. (1999). 'Competition for jobs and the emergence of dualism', Economic Journal, vol. 109, pp. 349-71. 